\title{
Article \\ Catalytic Ozonation of Toluene over Acidic Surface Transformed Natural Zeolite: A Dual-Site Reaction Mechanism and Kinetic Approach
}

\author{
Serguei Alejandro-Martín ${ }^{1} \mathbb{(}$, Héctor Valdés $^{2, *} \mathbb{C}$ and Claudio A. Zaror ${ }^{3}$ \\ 1 Wood Engineering Department, Faculty of Engineering, Universidad del Bío-Bío, Concepción 4030000, Chile; \\ salejandro@ubiobio.cl \\ 2 Clean Technologies Laboratory, Faculty of Engineering, Universidad Católica de la Santísima Concepción, \\ Concepción 4030000, Chile \\ 3 Chemical Engineering Department, Faculty of Engineering, Universidad de Concepción, \\ Concepción 4030000, Chile; czaror@udec.cl \\ * Correspondence: hvaldes@ucsc.cl
}

check for

updates

Citation: Alejandro-Martín, S.;

Valdés, H.; Zaror, C.A. Catalytic

Ozonation of Toluene over Acidic

Surface Transformed Natural Zeolite:

A Dual-Site Reaction Mechanism and Kinetic Approach. Catalysts 2021, 11, 958. https://doi.org/10.3390/ catal11080958

Academic Editors: Fernando J. Beltrán Novillo and Narendra Kumar

Received: 2 July 2021

Accepted: 6 August 2021

Published: 10 August 2021

Publisher's Note: MDPI stays neutral with regard to jurisdictional claims in published maps and institutional affiliations.

Copyright: (c) 2021 by the authors. Licensee MDPI, Basel, Switzerland. This article is an open access article distributed under the terms and conditions of the Creative Commons Attribution (CC BY) license (https:// creativecommons.org/licenses/by/ $4.0 /)$.

\begin{abstract}
Volatile organic compounds (VOCs) are responsible for damage to health due to their carcinogenic effects. Catalytic ozonation using zeolite appears as a valuable process to eliminate VOCs from industrial emissions at room temperature. For full-scale application of this new abatement technology, an intrinsic reaction rate equation is needed for an effective process design and scale-up. Results obtained here provide a mechanistic approach during the initial stage of catalytic ozonation of toluene using an acidic surface transformed natural zeolite. In particular, the contribution of Lewis and Brønsted acid sites on the surface reaction mechanism and overall kinetic rate are identified through experimental data. The least-squares non-linear regression method allows the rate-determining step to be established, following a Langmuir-Hinshelwood surface reaction approximation. Experimental evidence suggest that ozone is adsorbed and decomposed at Lewis acid sites, forming active atomic oxygen that leads to the oxidation of adsorbed toluene at Brønsted acid sites.
\end{abstract}

Keywords: catalytic ozonation; Lewis and Brønsted acid sites; natural zeolite; reaction mechanism; toluene

\section{Introduction}

Volatile organic compounds (VOCs), such as benzene, toluene, ethylbenzene, and xylene (BTEX) are emitted from a wide variety of sources, such as internal combustion engines, power stations, refineries, the food processing industry, the forestry industry, wastewater treatment facilities, and the dry cleaning industry, among other industrial sectors [1,2]. VOCs are also released from indoor sources, including: construction materials, damaged furniture, aerosol sprays, deodorants, air fresheners, cleaning products, disinfectants and insecticides [3]. BTEX are considered priority pollutants due to their toxic, mutagenic, and carcinogenic effects [4], and their role in the formation of secondary atmospheric pollutants such as ozone and airborne particulate matter [5].

During the last decades, great efforts have been made to remove VOCs from both indoor and outdoor emissions, using recovery methods (e.g., absorption, adsorption, membrane separation, and condensation) or destructive methods (e.g., thermal, catalytic, or biological oxidation) [6]. However, the disposal of VOC-saturated solvents or exhausted adsorbents from recovery processes has impaired large-scale implementation. Moreover, conventional destruction methods such as thermal oxidation might generate undesirable or noxious by-products, such as dioxins and carbon monoxide, and must be applied below the lower explosive level (LEL) of target VOCs. In the case of biological oxidation, special attention should be paid to avoid microorganism deactivation [7]. Alternatively, catalytic 
oxidation is claimed to be the most effective and economically feasible technique for the oxidation of VOCs into less harmful compounds and, eventually, into carbon dioxide and water [8,9]. Catalytic oxidation could be applied to treat waste gas streams in a wide range of VOCs concentrations and flow rates at temperatures around $473 \mathrm{~K}$. This technique can be considered as environmentally friendly due to its low energy demand and lower generation of harmful products, using appropriate catalysts [9-12].

Recently, a new catalytic process to oxidize VOCs using ozone has attracted increasing interest [13-18]. Ozone-based catalytic oxidation allows removing persistent VOCs from industrial emissions at room temperature, reducing operational cost [19-22]. Synthetic zeolites and metal-supported catalysts have been used as catalysts in the catalytic ozonation of VOCs [19,23-28]. Additionally, natural zeolites have started to be applied in combination with ozone in this abatement process $[29,30]$. Thus, some studies have indicated the positive contribution of modified natural zeolite on the catalytic treatment [31,32]. Even though the influence of surface acid sites of natural zeolites has been assessed in previous studies, there are still some doubts about the reaction mechanism that takes place among ozone and VOC interactions at the zeolite surface and there is also a lack of a kinetic expression to allow process scale-up.

For commercial-scale implementation of catalytic ozonation of VOCs using zeolite at room temperature, accurate kinetic rate expressions are needed to allow reactor design and optimization. In this study, the contribution of Lewis and Brønsted acid sites on the surface reaction mechanism is established and an overall kinetic model, representing the catalytic ozonation of toluene over acidic surface-transformed natural zeolite at room temperature, is proposed.

\section{Results and Discussion}

\subsection{FTIR Evidence of the Heterogeneous Catalytic Ozonation of Toluene}

Figure 1 displays FTIR spectra of uncovered acidic transformed natural zeolite sample (dashed line), upon contact with toluene (dotted line), and after catalytic ozonation experiments (solid line). An IR vibration band around $3584 \mathrm{~cm}^{-1}$ is observed in the uncovered and toluene-saturated samples. Such an IR band is related to acidic bridging hydroxyl groups $(\mathrm{Si}(\mathrm{OH}) \mathrm{Al})$ on natural zeolite, as reported elsewhere $[33,34]$.

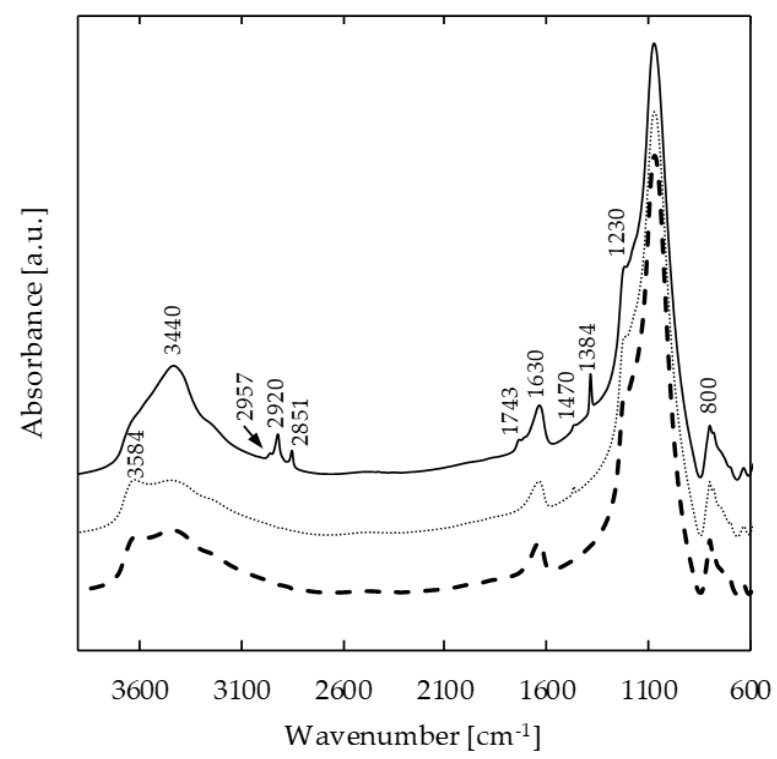

Figure 1. In situ FTIR spectra of acidic transformed natural zeolite (AZ) samples: uncovered AZ sample (dashed line); AZ sample saturated with toluene (dotted line); AZ sample after catalytic ozonation (solid line). 
The IR spectrum after toluene adsorption shows an IR band at $1470 \mathrm{~cm}^{-1}$ that is linked to adsorbed toluene molecules. In particular, the IR bands around $1450-1540 \mathrm{~cm}^{-1}$ (considering a maximum at 1477) have been associated with the stretching vibrations of $\mathrm{C}=\mathrm{C}$ bonds of the aromatic ring of adsorbed toluene on zeolites [35]. After catalytic ozonation of toluene, chemical surface intermediaries are identified in the collected spectrum (solid line). A typical absorption band at $1384 \mathrm{~cm}^{-1}$ is registered. This IR band is associated with active oxygen species formed at the zeolite surface [36-39]. Therefore, it can be related to ozone adsorption and decomposition at Lewis acid sites. It has been suggested that ozone is adsorbed and decomposed into atomic oxygen $\left(\mathrm{O}^{\bullet}\right)$ at Lewis acid sites, as represented by Equation (1) [37-44].

$$
\mathrm{O}_{3(g)}+s_{L} \rightleftharpoons \mathrm{O}^{\bullet}-s_{L}+\mathrm{O}_{2(g)}
$$

The IR bands at 1057 and $1027 \mathrm{~cm}^{-1}$, as well as the bands around $800 \mathrm{~cm}^{-1}$ and $1168 \mathrm{~cm}^{-1}$, have been ascribed to molecular ozone adsorption, ozonide species $\left(\mathrm{O}_{3}{ }^{-}\right)$, and superoxide $\left(\mathrm{O}_{2}{ }^{-}\right)$, respectively [33]. However, no significant differences on these adsorption bands (before and after ozone exposure) can be observed here, probably due to a rapid generation of atomic oxygen $\left(1384 \mathrm{~cm}^{-1}\right)$ at strong Lewis surface acid sites.

Additionally, an IR band at $1743 \mathrm{~cm}^{-1}$ is registered after catalytic ozonation (see solid line in Figure 1). IR bands around 1718-1752 $\mathrm{cm}^{-1}$ have been associated with adsorbed formic acid [45,46]. Additionally, some other distinctive peaks can be seen at 2851, 2920, and $2957 \mathrm{~cm}^{-1}$ after catalytic ozonation. IR bands around 2899 and $2935 \mathrm{~cm}^{-1}$ have been related to the $(\mathrm{C}-\mathrm{H})$ stretching vibrations of formate species [47]. Thus, the observed IR bands could be due to the shift of such IR bands associated with adsorbed toluene oxidation by-products. Complementary results obtained using HPLC analyses indicate the presence of formic acid, acetaldehyde, benzoic acid, and benzaldehyde as the main intermediate surface compounds after catalytic ozonation of toluene [48]. Furthermore, different studies of catalytic ozonation of toluene using different catalysts have shown that ozone is decomposed into active oxygen species, interacting with adsorbed toluene $[24,49,50]$. Therefore, it has been indicated that toluene is oxidized via methyl interaction. The lower dissociation energy of the methyl $\mathrm{C}-\mathrm{H}$ bond $(3.7 \mathrm{eV})$ could support that statement. This value is lower than the dissociation energies of other $\mathrm{C}-\mathrm{H}$ bonds of toluene molecule $(\mathrm{C}-\mathrm{H}$ bond of aromatic ring $4.3 \mathrm{eV}$; $\mathrm{C}-\mathrm{C}$ bond of methyl $4.4 \mathrm{eV}$; C-C bond of aromatic ring $5.0-5.3 \mathrm{eV}$; $\mathrm{C}=\mathrm{C}$ bond of the ring $5.5 \mathrm{eV}$ ), which justifies the schematic reaction route displayed in Figure 2. Thus, benzaldehyde, benzoic acid, and formic acid have been identified as primary reaction intermediates of catalytic ozonation of toluene in agreement with the results obtained in this work $[15,48,51,52]$.

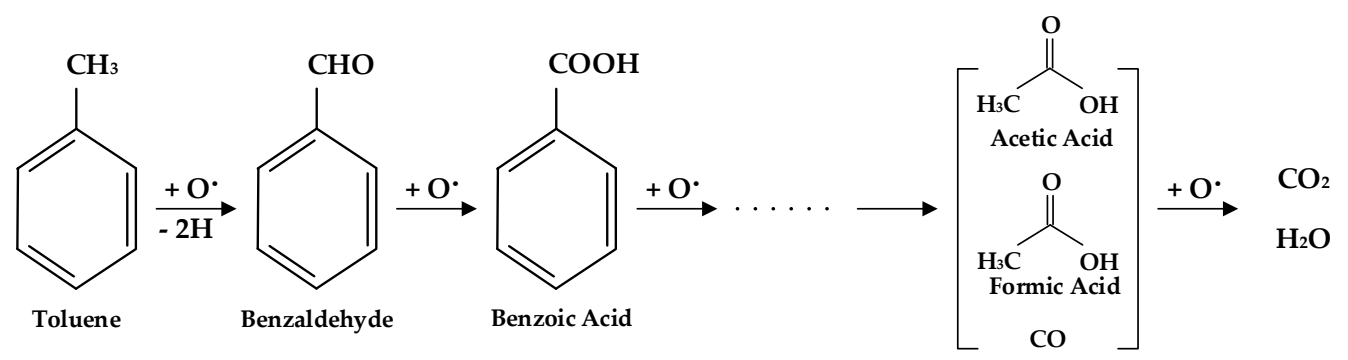

Figure 2. Proposed initial schematic route of the reaction of adsorbed toluene molecules with immediately adjacent adsorbed active oxygen species, forming toluene oxidation by-products. Reprinted with permission from references [51,53,54]. Copyright 2021 Elsevier.

IR evidence obtained here suggests that a surface reaction occurs between adsorbed toluene at Brønsted acid sites and active oxygen species generated after ozone adsorption and decomposition at Lewis acid sites. Such a surface reaction mechanism is in agreement with previous reports, that claim the adsorption of toluene molecules at Brønsted acid sites and the adsorption of ozone molecules at Lewis acid sites followed by its transformation 
into active oxygen species [32,48,55-57]. After that, it has been indicated that active oxygen species interact with adsorbed toluene molecules, leading to the formation of toluene oxidation by-products, as reported elsewhere [58,59]. Previously published works confirm the surface reaction mechanism proposed here, using not only natural zeolite mainly composed of clinoptilolite and mordenite and modified natural zeolite [32,48]; but also using synthetic zeolites such as faujasite, mordenite, and ZSM-5 [55-57] under the same experimental conditions.

\subsection{Kinetic Approaches of Catalytic Ozonation of Toluene}

In the absence of mass transfer limitations, the heterogeneous catalytic ozonation of toluene using acidic transformed natural zeolite can be represented by a general and simplified reaction, as follows [58,59]:

$$
\mathrm{C}_{7} \mathrm{H}_{8}+6 \mathrm{O}_{3} \stackrel{\text { cat }}{\rightarrow} 7 \mathrm{CO}_{2}+4 \mathrm{H}_{2} \mathrm{O}
$$

Firstly, a power law kinetic model is used here as an initial approximation for the estimation of the overall kinetic rate expression of catalytic ozonation of toluene, $r_{T o l}\left(\mu \mathrm{mol} \cdot \mathrm{dm}^{-3} \mathrm{~s}^{-1}\right)$ :

$$
-r_{T o l}=k_{a p p} C_{C_{7} H_{8}}^{\alpha} \cdot C_{\mathrm{O}_{3}}^{\beta}
$$

where $k_{a p p}$ is the apparent reaction rate constant $\left(\left(\mathrm{dm}^{3} \cdot \mu \mathrm{mol}\right)^{1+\alpha+\beta} \cdot \mathrm{s}^{-1}\right) ; C_{\mathrm{C}_{7} \mathrm{H}_{8}}$ and $C_{\mathrm{O}_{3}}$ stand for toluene and ozone concentrations $\left(\mu \mathrm{mol} \cdot \mathrm{dm}^{-3}\right)$, respectively; $\alpha$ and $\beta$ are orders of reaction related to toluene and ozone, respectively. Table 1 lists such kinetic parameters obtained after applying the NLR technique, using the tools of the Microsoft Excel Solver add-in [60]. Results are compared with others reported in the literature for catalytic ozonation of toluene using different catalysts.

As can be seen, the order of reaction obtained for toluene is lower than the order of reaction for ozone, which is evidence of the higher ozone dependence during catalytic ozonation of toluene promoted by acidic transformed natural zeolite. Moreover, the obtained apparent activation energy $\left(17.21 \mathrm{~kJ} \cdot \mathrm{mol}^{-1}\right)$ is lower than the reported activation energy in the toluene-ozone homogenous reaction $\left(55.5 \mathrm{~kJ} \cdot \mathrm{mol}^{-1}\right)$ [61]. Such results clearly indicate that active surface sites of acidic transformed natural zeolite play a significant role during the heterogeneous reaction.

\begin{tabular}{|c|c|c|c|c|c|c|c|}
\hline Catalysts & $\begin{array}{c}\text { Reaction } \\
\text { Temperature } \\
\text { (K) }\end{array}$ & $\begin{array}{c}k_{a p p} \times \mathbf{1 0}^{3} \\
\left(\mathbf{d m}^{3} \cdot \mu \mathbf{m o l}\right)^{\left.\mathbf{1 + \alpha + \beta} \cdot \mathbf{s}^{-1}\right)}\end{array}$ & $\frac{\mathrm{E}_{\mathrm{A} \text { app }}}{\left(\mathrm{kJ} \cdot \mathrm{mol}^{-1}\right)}$ & $\alpha$ & $\beta$ & $\mathbf{R}^{2}$ & Reference \\
\hline $\mathrm{AZ}$ & 293 & 5.07 & 17.21 & 0.66 & 0.82 & 0.97 & $\begin{array}{l}\text { This } \\
\text { study }\end{array}$ \\
\hline $\mathrm{MnO}_{2}$ /graphene & 295 & 3.25 & 29.3 & 0.63 & 0.55 & 0.91 & [62] \\
\hline $\mathrm{MnOx} / \gamma$-alumina & 343 & n.r & 31 & -1 & 2 & n.r & [63] \\
\hline $\mathrm{MnOx} / \gamma$-alumina & 298 & n.r & 33 & 0.18 & 0.56 & 0.98 & [64] \\
\hline
\end{tabular}

Table 1. Power law kinetic parameters for catalytic ozonation of toluene.

n.r: non-reported.

Secondly, a kinetic expression that takes into account the contribution of acidic surface sites of transformed natural zeolite during the catalytic ozonation of toluene is postulated following the dual-site Langmuir-Hinshelwood (dsL-H) surface reaction approximation and is validated using the experimental data collected during this study. It is assumed that all chemical species react after their adsorption at acidic surface sites, and each active site is occupied by only one reactive specie $[65,66]$. Thus, previous experimental results can be taken as shreds of evidence of the existence of two main active acidic surface sites where selective adsorption of toluene and ozone occur. Toluene has proved its affinity toward Brønsted acid sites and ozone for Lewis acid sites $[32,67,68]$. Hence, the surface reaction 
mechanism could be described by three elementary steps, including a dual-site surface reaction as the rate-determining step (RDS), as follows:

1. Ozone adsorption and decomposition at Lewis acid sites $\left(S_{L}\right)$ could be described by a simplified adsorption-desorption rate equation, $r_{1}\left(\mu \mathrm{mol} \cdot \mathrm{g}^{-1} \cdot \mathrm{s}^{-1}\right)$, as follows:

$$
O_{3}(g)+s_{L} \underset{k_{-1}}{\stackrel{k_{1}}{\rightleftharpoons}} O^{\bullet}-s_{L}+O_{2(g)} r_{1}=k_{1} C_{O_{3}}\left[s_{L}\right]-k_{-1}\left[O^{\bullet}-s_{L}\right] C_{O_{2}}
$$

where $\left[s_{L}\right]$ and $\left[O^{\bullet}-s_{L}\right]$ represent the total vacant Lewis acid sites of acidic transformed natural zeolite or the total surface concentration of Lewis acid sites $\left(\mu \mathrm{mol} \cdot \mathrm{g}^{-1}\right)$, and active atomic oxygen specie adsorbed at Lewis acid sites $\left(\mu \mathrm{mol} \cdot \mathrm{g}^{-1}\right)$, respectively. $k_{1}$ and $k_{-1}$ represent forward and reverse rate constants of active atomic oxygen surface specie formation $\left(\mathrm{dm}^{3} \cdot \mathrm{s}^{-1} \cdot \mu \mathrm{mol}^{-1}\right), \mathrm{C}_{\mathrm{O}_{3}}$ is the concentration of ozone $\left(\mu \mathrm{mol} \cdot \mathrm{dm}^{-3}\right)$ and $\mathrm{C}_{\mathrm{O}_{2}}$ is the concentration of oxygen $\left(\mu \mathrm{mol} \cdot \mathrm{dm}^{-3}\right)$.

2. Toluene adsorption at Brønsted acid sites $\left(S_{B}\right)$ could be represented by a simplified adsorption-desorption rate equation, $r_{2}\left(\mu \mathrm{mol} \cdot \mathrm{g}^{-1} \cdot \mathrm{s}^{-1}\right)$, as follows:

$$
C_{7} H_{8}(g)+s_{B} \underset{k_{-2}}{\stackrel{k_{2}}{\rightleftharpoons}} C_{7} H_{8}-s_{B} r_{2}=k_{2} C_{C_{7} H_{8}}\left[s_{B}\right]-k_{-2}\left[C_{7} H_{8}-s_{B}\right]
$$

where $\left[s_{B}\right]$ and $\left[C_{7} H_{8}-s_{B}\right]$ represent the total vacant Brønsted acid sites of acidic transformed natural zeolite or the total surface concentration of Brønsted acid sites $\left(\mu \mathrm{mol} \cdot \mathrm{g}^{-1}\right)$, and toluene-adsorbed specie at Brønsted acid sites $\left(\mu \mathrm{mol} \cdot \mathrm{g}^{-1}\right)$, respectively. $k_{2}$ represents forward rate constant of toluene surface complex formation $\left(\mathrm{dm}^{3} \cdot \mathrm{s}^{-1} \cdot \mu \mathrm{mol}^{-1}\right), k_{-2}$ represents the reverse rate constant of toluene surface complex formation $\left(\mathrm{s}^{-1}\right), \mathrm{C}_{\mathrm{C}_{7} \mathrm{H}_{8}}$ is the concentration of toluene $\left(\mu \mathrm{mol} \cdot \mathrm{dm}^{-3}\right)$.

3. Dual-site surface reaction (rate-determining step) $r_{3}\left(\mu \mathrm{mol} \cdot \mathrm{g}^{-1} \cdot \mathrm{s}^{-1}\right)$, between adsorbed toluene molecules at Brønsted acid sites and active oxygen species adsorbed at Lewis acid sites, leading to the formation of toluene oxidation by-products, as follows:

$$
\mathrm{C}_{7} \mathrm{H}_{8}-s_{B}+\mathrm{O}^{\bullet}-s_{L} \stackrel{k_{3}}{\rightarrow} \mathrm{C}_{7} \mathrm{H}_{6} \mathrm{O}-s_{B}+s_{L}-r_{3}=k_{3}\left[\mathrm{O}^{\bullet}-s_{L}\right]\left[\mathrm{C}_{7} \mathrm{H}_{8}-s_{B}\right]
$$

where $\left[\mathrm{C}_{7} \mathrm{H}_{8}-s_{B}\right]$ and $\left[\mathrm{O}^{\bullet}-s_{L}\right]$ stand for the amount of toluene adsorbed at Brønsted acid sites $\left(\mu \mathrm{mol} \cdot \mathrm{g}^{-1}\right)$, and the amount of active oxygen species adsorbed at Lewis acid sites $\left(\mu \mathrm{mol} \cdot \mathrm{g}^{-1}\right)$, respectively. $k_{3}$ is the disappearance rate constant of the adsorbed toluene surface complex $\left(\mathrm{g} \cdot \mathrm{s}^{-1} \cdot \mu \mathrm{mol}^{-1}\right)$.

The unknown surface concentrations of vacant sites of Lewis $\left[S_{L}\right]$ and Brønsted $\left[S_{B}\right]$ acidic sites can be calculated from site balances, as follows:

$$
\begin{gathered}
C_{L_{t}}=\left[s_{L}\right]+\left[O^{\bullet}-s_{L}\right] \\
C_{B_{t}}=\left[s_{B}\right]+\left[C_{7} H_{8}-s_{B}\right]
\end{gathered}
$$

where $C_{L t}$ and $C_{B t}$ are the total site concentration of Lewis acid sites $\left(\mu \mathrm{mol} \cdot \mathrm{g}^{-1}\right)$ and Brønsted acid sites $\left(\mu \mathrm{mol} \cdot \mathrm{g}^{-1}\right)$, respectively; $\left[\mathrm{O}^{\bullet}-s_{L}\right]$ and $\left[\mathrm{C}_{7} \mathrm{H}_{8}-s_{B}\right]$ represent adsorbed active oxygen specie $\left(\mu \mathrm{mol} \cdot \mathrm{g}^{-1}\right)$ and adsorbed toluene molecule $\left(\mu \mathrm{mol} \cdot \mathrm{g}^{-1}\right)$ at Lewis and Brønsted acid sites, respectively.

Here, use is made of the steady-state approximation for the rate of ozone adsorption and its decomposition into active atomic oxygen and for the rate of toluene adsorption. This assumes that $r_{1} \simeq 0$ and $r_{2} \simeq 0$ or the right-hand sides of Equations (4) and (5) are in a pseudo-equilibrium or stationary state.

Thus, the unknown concentration of active atomic oxygen specie adsorbed at Lewis acid sites can be estimated from Equation (4), assuming $r_{1} \simeq 0$, as follows:

$$
\left[O^{\bullet}-s_{L}\right]=\frac{k_{1} C_{O_{3}}\left[s_{L}\right]}{k_{-1} C_{O_{2}}}=K_{1} \frac{C_{O_{3}}\left[s_{L}\right]}{C_{O_{2}}}
$$


Since the inlet concentration of oxygen in all experiments was kept in excess, the oxygen concentration can be considered to remain constant. Thus, a new constant can be set as indicated by Equation (10):

$$
K_{1}^{\prime}=\frac{K_{1}}{C_{O_{2}}}
$$

Then, the unknown concentration of adsorbed active oxygen species can be finally obtained, as follows:

$$
\left[O^{\bullet}-s_{L}\right]=K_{1}^{\prime} C_{O_{3}}\left[s_{L}\right]
$$

Substituting Equation (11) into Equation (7) yields Equation (13):

$$
\begin{gathered}
C_{L_{t}}=\left[s_{L}\right]+K_{1}^{\prime} C_{O_{3}}\left[s_{L}\right]=\left[s_{L}\right]\left(1+K_{1}^{\prime} C_{O_{3}}\right) \\
{\left[s_{L}\right]=\frac{C_{L_{t}}}{\left(1+K_{1}^{\prime} C_{O_{3}}\right)}}
\end{gathered}
$$

In the case of the unknown concentration of adsorbed toluene molecules at Brønsted acid sites, it can be estimated from Equation (5) at a pseudo-equilibrium condition $\left(r_{2} \simeq 0\right)$, leading to:

$$
\left[\mathrm{C}_{7} \mathrm{H}_{8}-s_{B}\right]=\frac{k_{2}}{k_{-2}} \mathrm{C}_{\mathrm{C}_{7} \mathrm{H}_{8}}\left[s_{B}\right]=K_{2} \mathrm{C}_{\mathrm{C}_{7} \mathrm{H}_{8}}\left[s_{B}\right]
$$

Then, Equation (14) can be combined with Equation (8) to obtain Equation (16):

$$
\begin{gathered}
C_{B_{t}}=\left[s_{B}\right]+K_{2} C_{C_{7} H_{8}}\left[s_{B}\right]=\left[s_{B}\right]\left(1+K_{2} C_{C_{7} H_{8}}\right) \\
{\left[s_{B}\right]=\frac{C_{B_{t}}}{\left(1+K_{2} C_{C_{7} H_{8}}\right)}}
\end{gathered}
$$

After substituting Equations (11) and (14) in Equation (6) and then incorporating Equations (13) and (16), this yields Equation (18):

$$
\begin{gathered}
-r_{3}=k_{3}\left[C_{7} H_{8}-s_{B}\right]\left[O^{\bullet}-s_{L}\right]=k_{3} K_{2} C_{C_{7} H_{8}}\left[s_{B}\right] K_{1}^{\prime} C_{O_{3}}\left[s_{L}\right] \\
-r_{3}=K_{1}^{\prime} K_{2} k_{3} C_{L_{t}} C_{B_{t}} \frac{C_{O_{3}} C_{C_{7} H_{8}}}{\left(1+K_{1}^{\prime} C_{O_{3}}\right)\left(1+K_{2} C_{C_{7} H_{8}}\right)}
\end{gathered}
$$

In Equation (18) the values of $K_{2}$ and $C_{B_{t}}$ can be obtained from adsorption experiments since $K_{2}$ is the Langmuir adsorption equilibrium constant of toluene surface complex formation at Brønsted acid sites $\left(\mathrm{dm}^{3} \cdot \mu \mathrm{mol}^{-1}\right)$ and $C_{B_{t}}$ is the maximum toluene uptake, corresponding to the saturation of Brønsted acid sites or monolayer coverage $\left(\mu \mathrm{mol} \cdot \mathrm{g}^{-1}\right)$. Such equilibrium parameters come by substituting Equation (8) into Equation (14), resulting in Equation (19), as follows:

$$
\left[C_{7} H_{8}-s_{B}\right]=\frac{K_{2} C_{C_{7} H_{8}} C_{B_{t}}}{1+K_{2} C_{C_{7} H_{8}}}
$$

where $C_{C_{7} H_{8}}$ is the concentration of toluene at the equilibrium $\left(\mu \mathrm{mol} \cdot \mathrm{dm}^{-3}\right),\left[C_{7} H_{8}-s_{B}\right]$ is the amount of toluene adsorbed at Brønsted acid sites $\left(\mu \mathrm{mol} \cdot \mathrm{g}^{-1}\right)$ at equilibrium, $C_{B_{t}}$ is the maximum toluene uptake, corresponding to the saturation of Brønsted acid sites or monolayer coverage $\left(\mu \mathrm{mol} \cdot \mathrm{g}^{-1}\right)$. Thus, equilibrium parameters are gathered experimentally from a set of breakthrough curves of q-concentration data obtained using Equation (26).

Figure 3 depicts the adsorption equilibrium data of toluene at $293 \mathrm{~K}$ over acidic transformed natural zeolite, computed from breakthrough curves using Equation (26). As can be seen, the Langmuir adsorption isotherm adjusts very well to the experimental data $\left(\mathrm{R}^{2}=0.9959\right)$. The maximum toluene uptake by Brønsted acid sites, $C_{B_{t}}\left(0.23429 \mu \mathrm{mol} \cdot \mathrm{g}^{-1}\right)$, and the adsorption equilibrium constant, $K_{2}\left(3.81 \mathrm{dm}^{3} \cdot \mu \mathrm{mol}^{-1}\right)$ were obtained from the intercept and the slope of the linearized form of Langmuir isotherm expression, respectively. 
Such equilibrium parameters agree with values found in previous works using natural and modified natural zeolite mainly composed by clinoptilolite and mordenite [39].
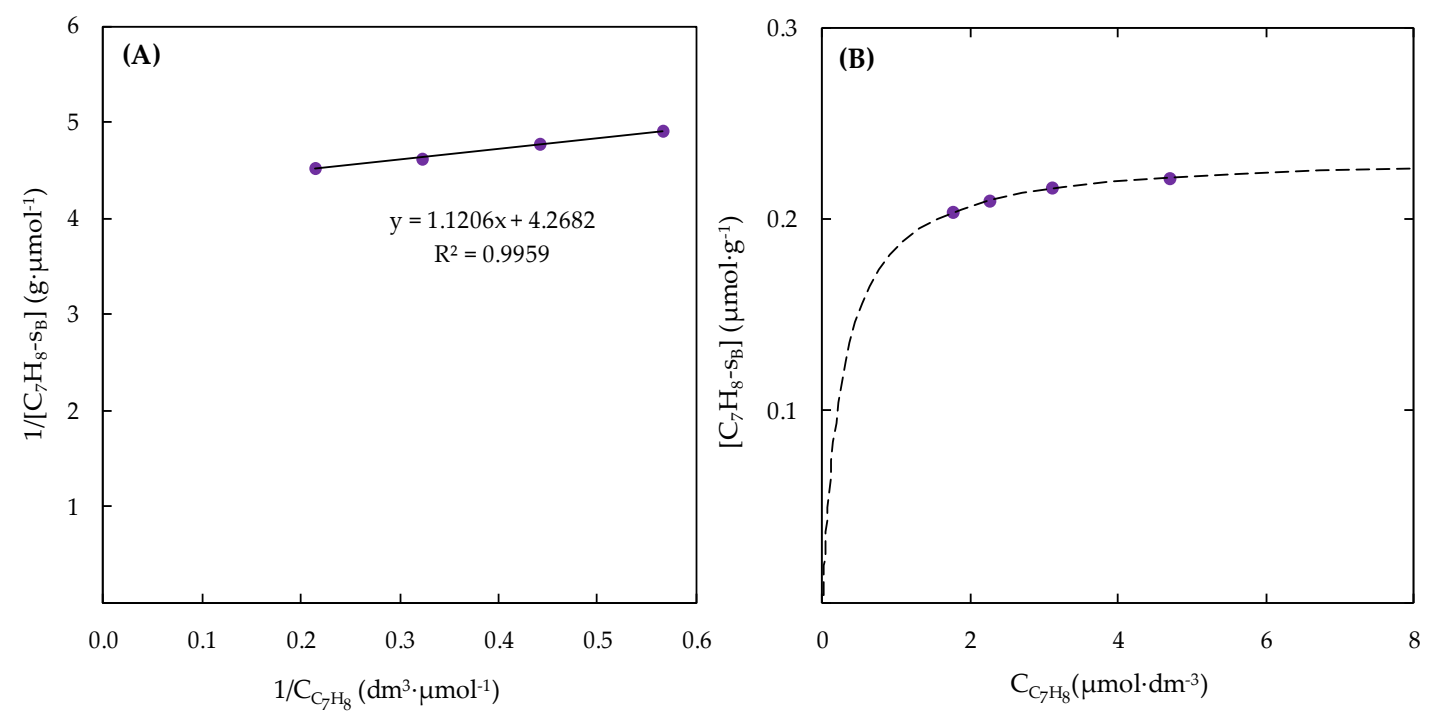

Figure 3. Adsorption equilibrium data of toluene at $293 \mathrm{~K}$ over acidic transformed natural zeolite: (A) linearized form of Langmuir adsorption model from Equation (22). (B) Langmuir adsorption model using Equation (22). (•) stands for experimental $q$ values calculated from Equation (3); (-) represents linearized form of Langmuir adsorption model; (- -) stands for Langmuir adsorption model.

If an apparent constant $k_{a p p}^{\prime}$ is defined as:

$$
k_{a p p}^{\prime}=K_{1}^{\prime} K_{2} k_{3} C_{L_{t}} C_{B_{t}}
$$

Then, the overall kinetic expression can be rewritten, as follows:

$$
-r_{3}=k_{a p p}^{\prime} \frac{C_{\mathrm{O}_{3}} \mathrm{C}_{\mathrm{C}_{7} \mathrm{H}_{8}}}{\left(1+K_{1}^{\prime} \mathrm{C}_{\mathrm{O}_{3}}\right)\left(1+K_{2} \mathrm{C}_{\mathrm{C}_{7} \mathrm{H}_{8}}\right)}
$$

Hence, substituting the obtained experimental equilibrium constant of toluene adsorption into Equation (21), gives:

$$
-r_{3}=k_{a p p}^{\prime} \frac{C_{\mathrm{O}_{3}} C_{\mathrm{C}_{7} \mathrm{H}_{8}}}{\left(1+K_{1}^{\prime} \mathrm{C}_{\mathrm{O}_{3}}\right)\left(1+3.81 C_{\mathrm{C}_{7} \mathrm{H}_{8}}\right)}
$$

Table 2 summarizes experimental and estimated reaction rate values of catalytic ozonation of toluene using acidic transformed natural zeolite. During a set of experimental runs, the inlet concentration ratio of toluene/ozone was varied from 5.3 to 37.8. The NLR technique was conducted to obtain model parameters of Equation (22), using the tools of the Microsoft Excel Solver add-in [60].

Finally, the proposed overall kinetic rate expression of catalytic ozonation of toluene at room temperature, using acidic transformed natural zeolite, is represented by Equation (23):

$$
-r_{3}=0.233 \frac{\mathrm{C}_{\mathrm{O}_{3}} \mathrm{C}_{\mathrm{C}_{7} \mathrm{H}_{8}}}{\left(1+0.063 \mathrm{C}_{\mathrm{O}_{3}}\right)\left(1+3.81 C_{\mathrm{C}_{7} \mathrm{H}_{8}}\right)}
$$

where the constants $k_{a p p}^{\prime}, K_{1}^{\prime}$, and $K_{2}$ take the values of $0.233\left(\mathrm{dm}^{3}\right)^{2} \cdot \mu \mathrm{mol}^{-1} \cdot \mathrm{g}^{-1} \cdot \mathrm{s}^{-1}$, $0.063 \mathrm{dm}^{3} \cdot \mu \mathrm{mol}^{-1}$, and $3.81 \mathrm{dm}^{3} \cdot \mu \mathrm{mol}^{-1}$, respectively.

Figure 4 shows a visual comparison of the obtained experimental and estimated reaction rate values of catalytic ozonation of toluene. An excellent coefficient of determination $\left(R^{2}=0.97\right)$ is obtained. A value of $R^{2}=0.91$ was reported previously by Hu et al. [62] using 
the dsL-H reaction approach in the catalytic ozonation of toluene over $\mathrm{MnO}_{2}$ /grapheme, suggesting that two active sites are involved in the reaction mechanism.

Table 2. Experimental and calculated reaction rate values.

\begin{tabular}{|c|c|c|c|c|c|c|}
\hline \multirow{2}{*}{ Runs } & \multicolumn{2}{|c|}{$\begin{array}{l}\text { Inlet Concentration } \\
\quad\left(\mu \mathrm{mol} \cdot \mathrm{dm}^{-3}\right)\end{array}$} & \multirow{2}{*}{$\begin{array}{c}\text { Conversion of } \\
\text { Toluene } \\
(\%)\end{array}$} & \multicolumn{3}{|c|}{$\begin{array}{c}-r_{3} \\
\left(\mu \mathrm{mol} \cdot \mathrm{g}^{-1} \cdot \mathrm{s}^{-1}\right)\end{array}$} \\
\hline & Toluene & Ozone & & Experimental & $\begin{array}{l}\text { Estimated by the } \\
\text { Power Law Model }\end{array}$ & $\begin{array}{c}\text { Estimated by the } \\
d s L-H \text { Model }\end{array}$ \\
\hline 1 & 42.36 & 3.57 & 11.0 & 0.207 & 0.1769 & 0.1810 \\
\hline 2 & 42.36 & 6.48 & 15.7 & 0.295 & 0.2876 & 0.2871 \\
\hline 3 & 42.36 & 6.48 & 14.4 & 0.272 & 0.2876 & 0.2871 \\
\hline 4 & 42.36 & 1.92 & 5.6 & 0.106 & 0.1054 & 0.1060 \\
\hline 5 & 42.36 & 1.12 & 3.0 & 0.057 & 0.0676 & 0.0646 \\
\hline 6 & 42.36 & 1.12 & 3.2 & 0.061 & 0.0676 & 0.0646 \\
\hline 7 & 42.86 & 1.92 & 4.3 & 0.081 & 0.1063 & 0.1068 \\
\hline 8 & 33.99 & 3.57 & 10.6 & 0.160 & 0.1519 & 0.1562 \\
\hline 9 & 33.85 & 6.43 & 16.8 & 0.253 & 0.2461 & 0.2456 \\
\hline 10 & 33.96 & 1.92 & 5.4 & 0.081 & 0.0910 & 0.0914 \\
\hline 11 & 50.99 & 3.57 & 9.3 & 0.212 & 0.1990 & 0.2032 \\
\hline 12 & 42.71 & 3.57 & 10.4 & 0.198 & 0.1768 & 0.1820 \\
\hline 13 & 42.36 & 1.79 & 4.3 & 0.081 & 0.0995 & 0.0995 \\
\hline 14 & 42.56 & 7.59 & 16.4 & 0.311 & 0.3287 & 0.3218 \\
\hline
\end{tabular}

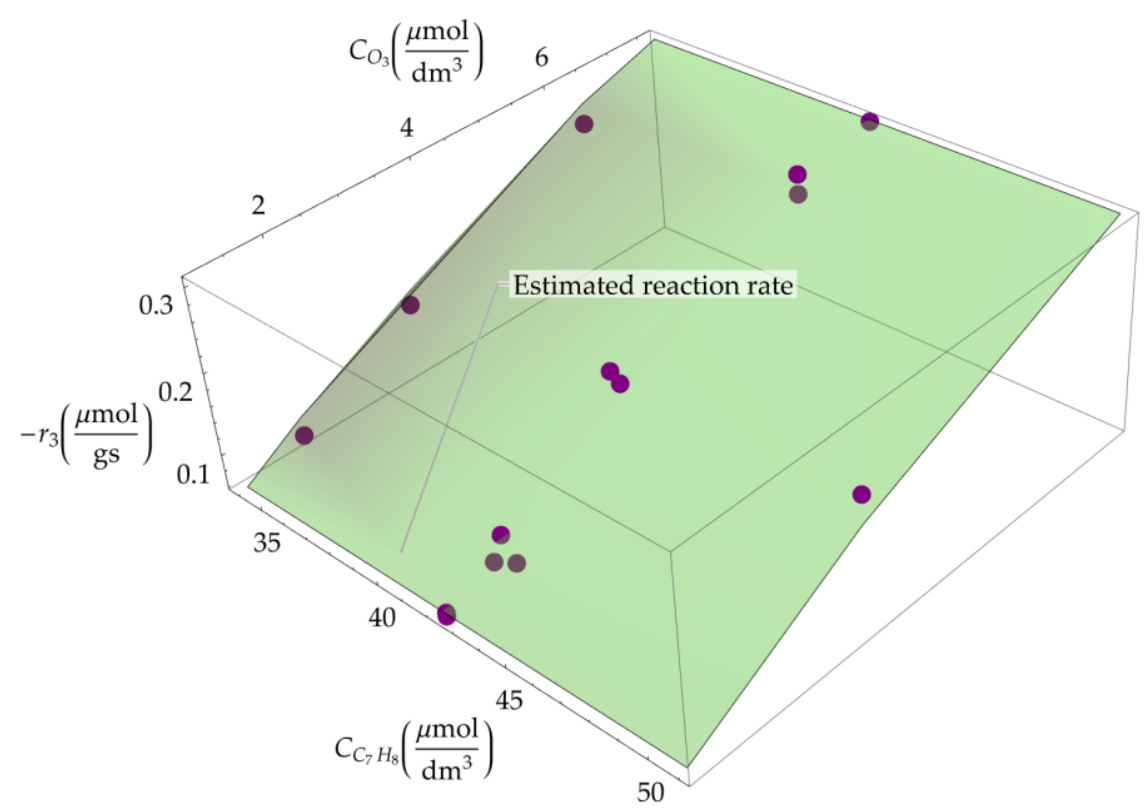

Figure 4. Fit between the proposed dsL-H kinetic reaction model and the experimental data reported in Table 2 for the catalytic ozonation of toluene using acidic surface-transformed natural zeolite, where the surface reaction between adsorbed species on adjacent active sites is the rate-determining step.

On the one hand, results obtained in this study provide evidence that the dsL-H reaction model shows a higher dependence of ozone toward Lewis acid sites during the catalytic ozonation of toluene. Such a result is in agreement with that obtained with the applied power law kinetic model. Our previous work [32], reported the influence of Lewis acid sites on the toluene ozonation reaction rate, using natural and modified zeolites. Experimental results evidenced a linear dependency (slope $=0.05$ ) of the registered reaction rate and Lewis acid sites. Consequently, a higher surface concentration of atomic oxygen enhances catalytic ozonation of toluene, in concordance with experimental findings reported before $[36,37,39,42-44]$. On the other hand, the influence of Brønsted strong acid sites density over toluene ozonation reaction rate also showed a linear dependency, 
resulting in a lower contribution (slope $=0.01$ ). Former studies reported the affinity of toluene for Brønsted acid sites [69,70]. However, this interaction might lower the reaction rate due to strong toluene adsorption at Brønsted acid sites. Therefore, surface acidic sites of the modified natural zeolite framework reveal a remarkable contribution to toluene ozonation at room temperature.

\section{Materials and Methods}

\subsection{Materials}

Chilean natural zeolite mainly composed of clinoptilolite (53\%), mordenite $(40 \%)$ and quartz $(7 \%)$ was acquired from Minera FORMAS ${ }^{\mathrm{TM}}$, Santiago, RM, Chile. As-received zeolite sample was ground and sieved. Particle sizes in the range $0.3-0.425 \mathrm{~mm}$ were used in the whole study and they were washed with de-ionized water, oven dried at $398 \mathrm{~K}$ and stored in a desiccator. This zeolite exhibits an apparent density, $2.3 \mathrm{~g} \cdot \mathrm{cm}^{-3}$; BET surface area, $205 \mathrm{~m}^{2} \mathrm{~g}^{-1}$; total pore volume, $0.11 \mathrm{~cm}^{3} \mathrm{~g}^{-1}$; cation exchange capacity, $2.05 \mathrm{meq} \cdot \mathrm{g}^{-1}$; with a Si/Al of 5.34; and it is mainly made up of $\mathrm{SiO}_{2}(75.25 \%)$ and $\mathrm{Al}_{2} \mathrm{O}_{3}(14.1 \%)$ followed by $\mathrm{CaO}(4.57 \%), \mathrm{Fe}_{2} \mathrm{O}_{3}(2.31 \%), \mathrm{Na}_{2} \mathrm{O}(1.89 \%), \mathrm{K}_{2} \mathrm{O}(0.74 \%), \mathrm{MgO}(0.66 \%), \mathrm{TiO}_{2}(0.42 \%)$, and $\mathrm{MnO}(0.05 \%)$; with a concentration of Brønsted and Lewis acid sites of $0.4 \mu \mathrm{mol} \cdot \mathrm{g}^{-1}$ and $31.1 \mu \mathrm{mol} \cdot \mathrm{g}^{-1}$, respectively [32]. Natural zeolite was used as a parent material to produce a zeolite sample with a higher content of acidic sites.

Ozone was generated in situ from instrumental dry air provided by AGA using an AZCOZON A-4 ozone generator (Vancouver, BC, Canada). A contaminated stream made of toluene vapors was used here as a target VOC. The stream enriched with toluene vapors was produced by continuously bubbling dry argon into a pure liquid toluene (confined in a flask at a controlled temperature of $261 \mathrm{~K}$ ). Toluene was supplied by Merck (Darmstadt, Hessen, Germany) with a purity of $99.8 \%$.

\subsection{Transformation of As-Received Natural Zeolite into a Modified Zeolite Rich in Acidic Sites}

Natural zeolite was modified by ion-exchange treatment using an ammonium sulphate solution $\left(0.1 \mathrm{~mol} \cdot \mathrm{dm}^{-3}\right)$ with a volume/solid ratio of $10 / 1$ at $363 \mathrm{~K}$ during $3 \mathrm{~h}$. Then, it was rinsed with ultra-pure water for $4 \mathrm{~h}$, replacing water after 2 and $3 \mathrm{~h}$ of contact time. After that, a second ion-exchange using the ammonium sulphate solution was applied using the same procedure and steps as described above. This modification method decreases the content of compensating cations, being ion-exchanged by ammonium cations. Then, ammonium-exchanged zeolite sample was oven-dried at $378 \mathrm{~K}$ for $24 \mathrm{~h}$ and stored in a desiccator until further use. Finally, a modified zeolite sample with a higher content of acid sites was produced just before the catalytic ozonation experiments by thermal outgassing at $823 \mathrm{~K}$ and it is identified here as AZ.

Nitrogen adsorption-desorption isotherms at $77 \mathrm{~K}, \mathrm{X}$-ray powder diffraction (XRD), $X$-ray fluorescence (XRF), scanning electron microscopy (SEM), energy-dispersive $X$-ray spectroscopy (EDS), and transmission electron microscopy (TEM) were conducted to characterize the transformed natural zeolite sample. Surface area $\left(\mathrm{S}_{\mathrm{BET}}\right)$ was obtained from nitrogen adsorption-desorption isotherms measured in a Micromeritics Gemini 3175 sorptometer (Norcross, GA, USA). The crystalline structure was registered by XRD analysis in a Bruker AXS Model D4 ENDEAVOR diffractometer (Billerica, MA, USA); the presence of main compensating cations was determined by X-ray fluorescence, using a RIGAKU Model 3072 spectrometer (Akishima, Tokyo Metropolis, Japan). SEM studies were carried out in a JEOL (Akishima, Tokyo Metropolis, Japan) JSM-6380 microscope, operating at $20 \mathrm{kV}$. Samples were ground to $150 \mu \mathrm{m}$ and a small amount was deposited in the apparatus. Chemical composition was measured by EDS coupled to the SEM microscope. TEM images were obtained with a JEOL (Akishima, Tokyo Metropolis, Japan), JEM 1200 EX-II device equipped with a Gatan 782 camera for Electron Microscope Erlangshen ES 500. Samples with a particle size of $150 \mu \mathrm{m}$ were deposited over a mesh previously covered by carbon. Analyses were carried out using an accelerating voltage of $120 \mathrm{kV}$. Additionally, the nature and strength of acidic sites were investigated by in situ Fourier transform infrared spectroscopy 
(FTIR), using pyridine as a probe molecule in adsorption and desorption assays followed by FTIR analysis (Py-FTIR), according to a procedure reported previously [32]. More details about characterization procedures can be found in other publications [67,71-74].

The XRD diffraction pattern of transformed natural zeolite showed no significant changes with respect to as-received natural zeolite, keeping the same crystalline structure after the applied ion-exchange treatments with ammonium sulphate (see Figure 5). Characteristic peaks of clinoptilolite $(\mathrm{C})$, mordenite $(\mathrm{M})$ and quartz $(\mathrm{Q})$ are noticed with equal intensity in both difractograms and were identified according to JCPDS 39-183, JCPDS 29-1257 and JCPDS 461045, respectively. However, XRF analysis revealed a reduction in the amount of compensating cations without any effect on the $\mathrm{Si} / \mathrm{Al}$ ratio (5.34). Thus, the modified zeolite sample is mainly composed by $\mathrm{SiO}_{2}(79.26 \%)$ and $\mathrm{Al}_{2} \mathrm{O}_{3}(14.85 \%)$ followed by $\mathrm{CaO}(1.82 \%), \mathrm{Fe}_{2} \mathrm{O}_{3}(2.53 \%), \mathrm{Na}_{2} \mathrm{O}(0.26 \%), \mathrm{K}_{2} \mathrm{O}(0.39 \%), \mathrm{MgO}(0.37 \%), \mathrm{TiO}_{2}$ $(0.47 \%)$, and $\mathrm{MnO}(0.05 \%)$. Table 3 lists the main physical-chemical characteristics of the acidic transformed natural zeolite sample. As expected, the surface area and the content of acidic sites in the form of both Brønsted and Lewis acid sites were increased with the applied modification treatment.

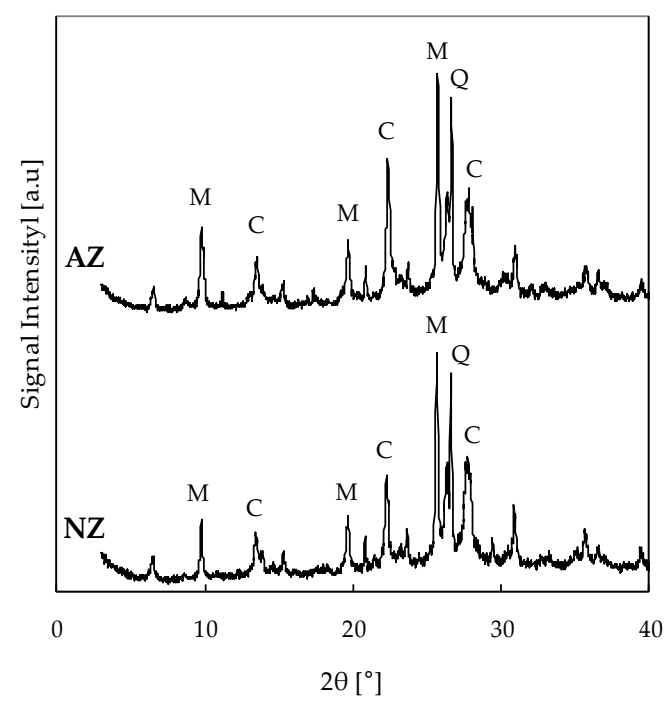

Figure 5. X-ray powder diffraction patterns of as-received natural zeolite (NZ) and acidic transformed natural zeolite (AZ) samples. Clinoptilolite (C), mordenite (M) and quartz (Q).

Table 3. Textural and acidic content of acidic transformed natural zeolite.

\begin{tabular}{|c|c|c|c|}
\hline $\begin{array}{c}\mathrm{S}_{\mathrm{BET}}{ }^{\mathrm{a}} \\
\left(\mathrm{m}^{2} \cdot \mathrm{g}^{-1}\right)\end{array}$ & $\begin{array}{l}\text { Brønsted }^{b} \\
\text { Acid Sites } \\
\left(\mu \mathrm{mol} \cdot \mathrm{g}^{-1}\right)\end{array}$ & $\begin{array}{c}\text { Lewis }^{b} \\
\text { Acid Sites } \\
\left(\mu \mathrm{mol} \cdot \mathrm{g}^{-1}\right)\end{array}$ & $\begin{array}{c}\text { Total } \\
\text { Acidity } \\
\left(\mu \mathrm{mol} \cdot \mathrm{g}^{-1}\right)\end{array}$ \\
\hline 261 & 179.8 & 282.8 & 462.6 \\
\hline
\end{tabular}

a Obtained from nitrogen adsorption-desorption isotherm. ${ }^{\mathrm{b}}$ Determined by in situ Py-FTIR analyses, quantifying the remaining adsorbed pyridine after heating the saturated-samples up to $823 \mathrm{~K}$.

SEM-EDS analyses (see Figure 6) corroborated the results obtained by XRD and XRF. A reduction in the content of compensating cations could be noticed in the as-received zeolite sample after the applied ion-exchange modification procedures. 

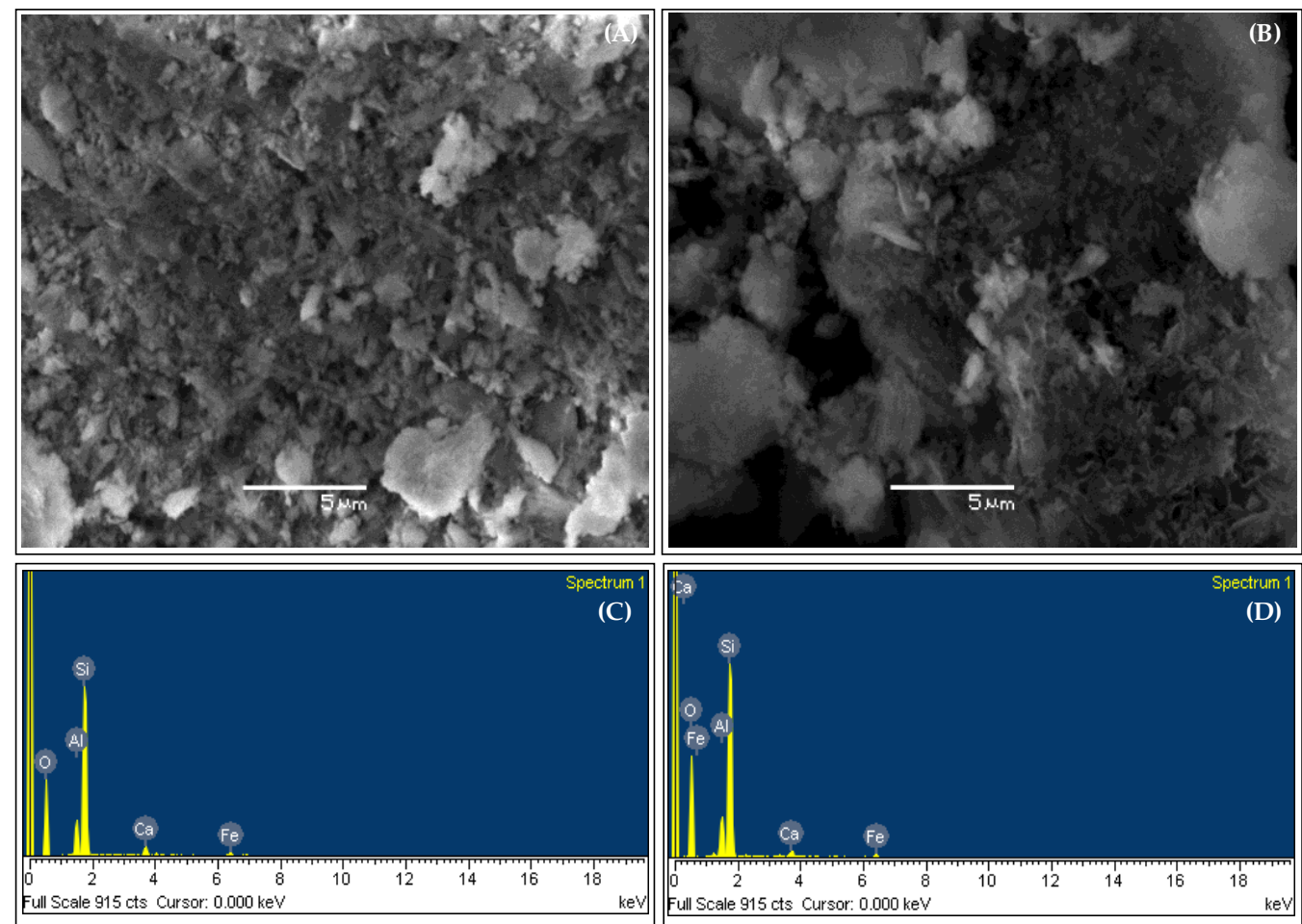

Figure 6. SEM-EDS results. $(A, C)$ natural zeolite; $(\mathbf{B}, \mathbf{D})$ acidic transformed natural zeolite.

EDS results shown in Figure 6 indicate a $49.1 \%$ and a $40.1 \%$ of decrease in the amount of $\mathrm{Ca}$ and Fe cations, respectively. Also, the Si/Al ratio obtained with this technique remained almost constant, confirming that the zeolite structure was not significantly changed. Based on previous experimental results $[32,67,68,71]$, a lower content of compensating cations has been related to a better ozone and toluene diffusion and accessibility to active surface sites of the zeolite framework, suggesting a better performance of acidic transformed natural zeolite during catalytic ozonation of VOCs.

TEM images of natural zeolite and acidic transformed natural zeolite samples are presented in Figure 7A,B, respectively. As can be seen, no substantial changes in the structure and morphology of zeolite samples are observed.
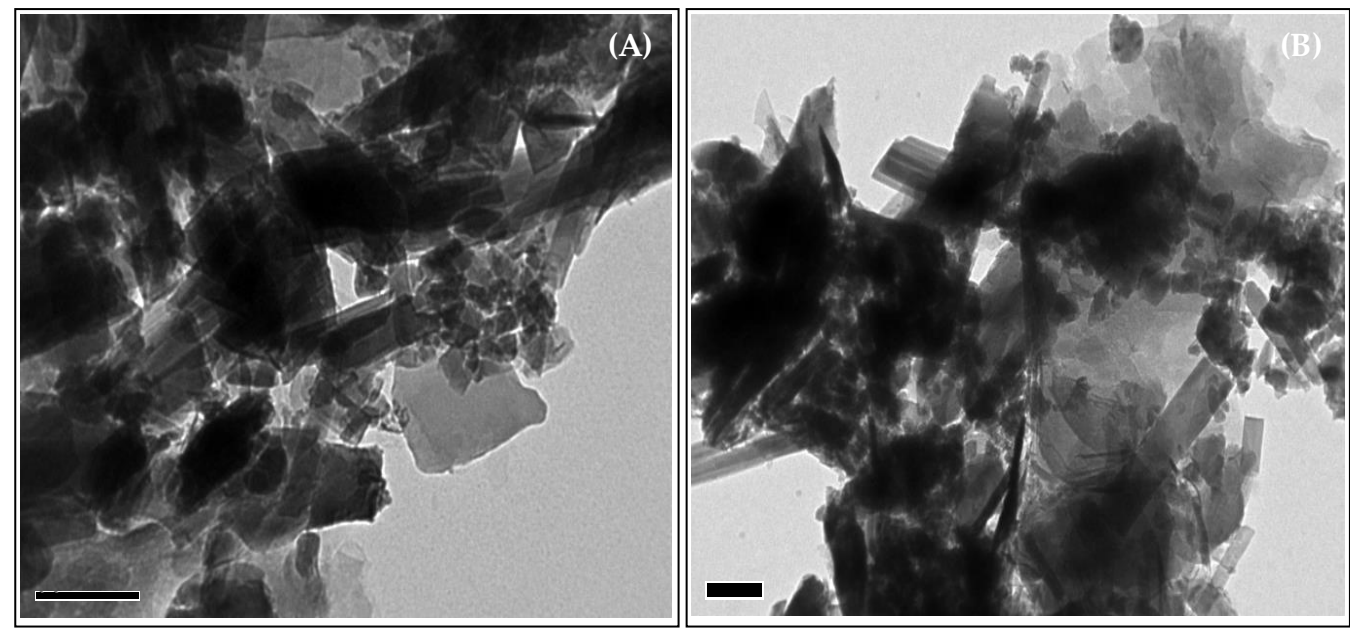

Figure 7. TEM images of (A) natural zeolite; (B) acidic transformed natural zeolite. 


\subsection{Experimental Description of Catalytic Ozonation Studies}

Catalytic ozonation experiments were conducted at $293 \mathrm{~K}$, using a U-type quartz packed-bed reactor (see Figure 8). Experimental conditions were set after preliminary experiments, following the Madon-Boudart criterion to assure the absence of mass transfer limitations [66]. Briefly, a mass of $150 \mathrm{mg}$ of zeolite sample mixed with quartz particles of the same size with a mass ratio of $1: 4\left(\mathrm{~d}_{\mathrm{p}} \approx 0.36 \mathrm{~mm}\right)$ was loaded and thermally outgassed (before reaction) at a heating rate of $1^{\circ} \mathrm{C} \cdot \mathrm{min}^{-1}$ under argon flow $\left(100 \mathrm{~cm}^{3} \cdot \mathrm{min}^{-1}\right)$ until reaching a temperature of $823 \mathrm{~K}$. Then, isothermal conditions were maintained for two hours, before being cooled down to room temperature. After that, at a temperature of $293 \mathrm{~K}$, a total gas flow of $100 \mathrm{~cm}^{3} \cdot \mathrm{min}^{-1}$ containing toluene and ozone was supplied over the reactor. Toluene and ozone concentrations were varied during the kinetic study, within ranges limited by physical chemical equilibria after dilutions of saturated streams and inert fresh streams. The concentrations of toluene and ozone were monitored on-line using a Perkin Elmer Clarus 500 chromatograph (Perkin Elmer, Waltham, MA, USA) and a BMT 964 ozone analyzer (BMT Messtechnik GmbH, Stahnsdorf, Germany), respectively. More details about experimental conditions and procedures can be found elsewhere [32]. All trials were performed in the absence of mass transfer limitations.

The reactor was operated in a differential mode. Thus, from a series of experimental runs, a set of rate-concentration data was obtained using the plug flow performance equation [65], as follows:

$$
\frac{W}{F_{T o l_{i n}}}=\frac{X_{\text {Tol }}}{\left(-r_{T o l}\right)_{\exp }}
$$

where $F_{T o l}$ in represents the feed rate of toluene $\left(\mu \mathrm{mol} \cdot \mathrm{s}^{-1}\right),\left(-r_{T o l}\right)_{\text {exp }}$ is the rate of catalytic oxidation reaction of toluene by ozone $\left(\mu \mathrm{mol} \cdot \mathrm{g}^{-1} \cdot \mathrm{s}^{-1}\right), W$ is the mass of zeolite sample $(\mathrm{g})$, and $X_{T o l}$ is the fraction of toluene converted.

In order to obtain a kinetic reaction model that represents the catalytic ozonation of toluene promoted by transformed natural zeolite at room temperature, firstly, a power law kinetic model was assessed as an initial approximation. Secondly, a set of several elementary steps were proposed with individual rates and an overall kinetic rate expression was postulated, considering the rate-determining step (RDS) by taking into account the experimental findings obtained in this study and those reported previously [32]. In both cases, the proposed overall rate expressions were validated with the experimental data using the least-squares non-linear regression method (NLR). Parameters of the proposed kinetic expressions were gathered by minimizing the sum of the squares $\left(\sigma^{2}\right)$ of the difference of obtained reaction rates for each experimental run, using the solver tool of Microsoft Excel [60] implemented through Equation (25).

$$
s^{2}=\sum_{i=1}^{14}\left[\left(\left(-r_{\text {Tol }}\right)_{\exp }-\left(-r_{\text {Tol }}\right)_{\text {mod }}\right)_{i}^{2}\right]
$$

where $\left(-r_{T o l}\right)_{\text {exp }}$ and $\left(-r_{T o l}\right)_{\text {mod }}$ stand for the rate of catalytic ozonation of toluene $\left(\mu \mathrm{mol} \cdot \mathrm{g}^{-1} \cdot \mathrm{s}^{-1}\right)$, obtained experimentally and using the proposed kinetic model, respectively.

Additionally, Langmuir adsorption equilibrium parameters were obtained from dynamic adsorption experiments conducted at $293 \mathrm{~K}$, using the same experimental set-up without the inlet of ozone. Prior to adsorption experiments, zeolite samples were thermally outgassed as described before. The adsorbed amounts of toluene over acidic transformed natural zeolite at equilibrium $\left(\mu \mathrm{mol} \cdot \mathrm{g}^{-1}\right)$ for different inlet concentrations of toluene, were calculated from breakthrough curves using Equation (26), as reported elsewhere [68].

$$
q=\frac{1}{W} \int_{0}^{t_{s}}\left(F_{T o l_{i n}}-F_{T o l_{t}}\right) d t
$$


where $q$ is the adsorbed amount of toluene over acidic transformed natural zeolite at equilibrium $\left(\mu \mathrm{mol} \cdot \mathrm{g}^{-1}\right) . W$ is the zeolite mass $(\mathrm{g})$, and $t_{s}$ is the time needed to reach the zeolite saturation (s). $F_{T o l_{i n}}$ and $F_{T o l_{t}}$ are the feed rate of toluene $\left(\mu \mathrm{mol} \cdot \mathrm{s}^{-1}\right)$, at the adsorber inlet and outlet streams as a function of time, respectively.

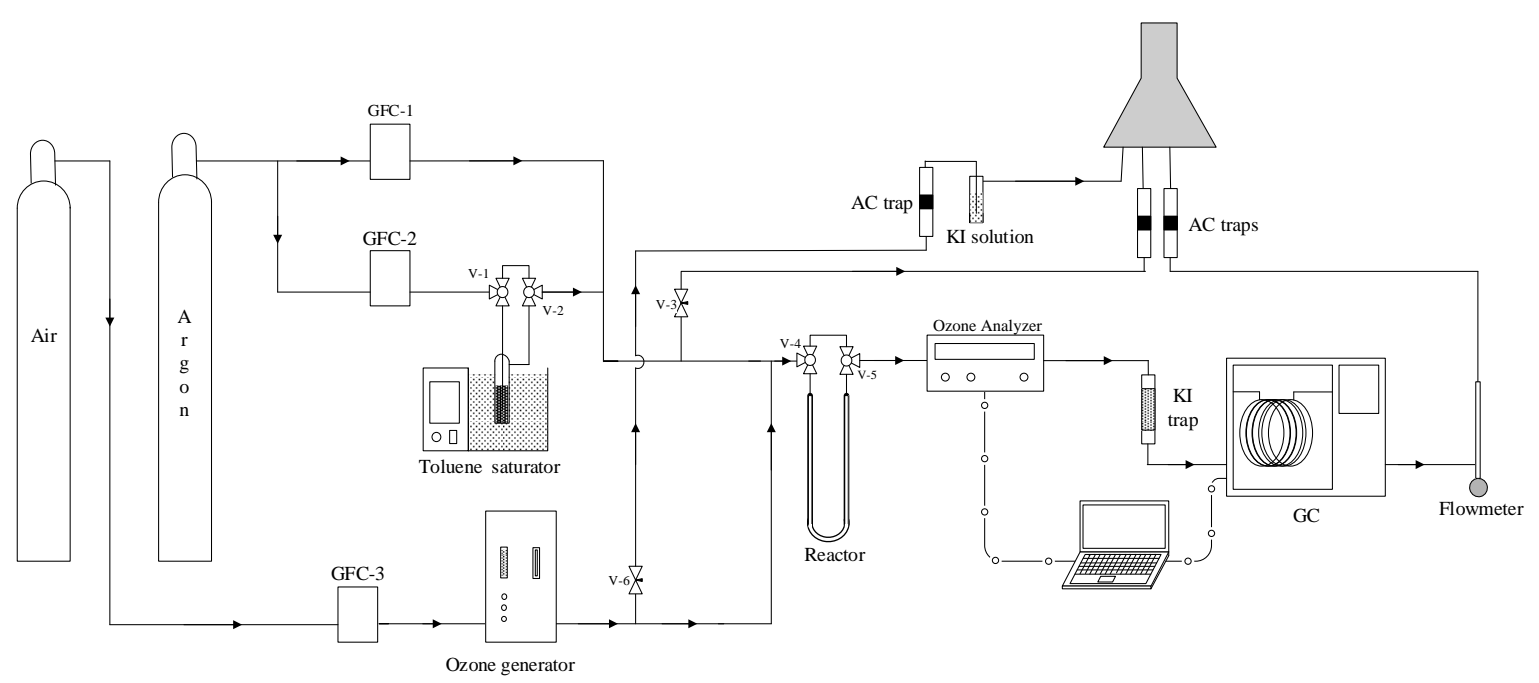

Figure 8. Experimental set-up for the catalytic ozonation of toluene using acidic surface transformed natural zeolite as catalyst at room temperature. Gas flow controllers (GFC); activated carbon (AC) traps; potassium iodine (KI) trap. Reprinted from Reference [32].

\subsection{In Situ FTIR Study of Surface Interactions between Zeolite Sample and Toluene Oxidation By-Products}

Oxidation by-products that remained adsorbed after catalytic ozonation of toluene were identified by FTIR spectroscopy in a Bruker Mod Tensor 27 spectrometer (Billerica, MA, USA). IR spectra were collected at an average of 100 scans with a resolution of $4 \mathrm{~cm}^{-1}$ using a self-pressed disc. Additionally, IR spectra before and after toluene adsorption were also recorded.

\section{Conclusions}

Results obtained in this study provide new insights on the surface reaction mechanism during the catalytic ozonation of toluene using acidic transformed natural zeolite. Experimental evidence confirmed that surface interactions take place between adsorbed toluene at Brønsted acid sites with active atomic oxygen, coming from ozone adsorption and decomposition at Lewis acid sites, leading to toluene oxidation. Experimental data proved that catalytic ozonation of toluene using acidic transformed natural zeolite is very well represented by the dual-site Langmuir-Hinshelwood (dsL-H) kinetic approximation where the rate-determining step results to be the surface reaction between adsorbed species on adjacent active sites. This kinetic expression can be used in the design and optimization of this new process technology. Acidic transformed natural zeolite could be applied as an effective and low-cost catalyst for the catalytic oxidation of VOCs using ozone at room temperature in a novel air pollution control technology. Further research using metalsupported modified natural zeolites in toluene oxidation is under way to complement information provided here in order to facilitate large scale implementation.

Author Contributions: Conceptualization, S.A.-M., H.V. and C.A.Z.; methodology S.A.-M. and H.V.; investigation, S.A.-M., H.V.; resources, H.V.; data curation, S.A.-M.; writing-original draft preparation, S.A.-M., H.V.; writing-review and editing, S.A.-M., H.V. and C.A.Z.; visualization, S.A.-M.; supervision, H.V. and C.A.Z.; project administration, H.V.; funding acquisition, H.V. All authors have read and agreed to the published version of the manuscript. 
Funding: This research was funded by CONICYT, FONDECYT/Regular, grant number 1130560 and by the Universidad Católica de la Santísima Concepción, grant number DI-FME 02/2021.

Data Availability Statement: Data presented in this study are available in the tables displayed inside this article.

Acknowledgments: The authors would like to thank Víctor Solar from the Clean Technology Laboratory, Universidad Católica de la Santísima Concepción for his valued collaboration.

Conflicts of Interest: The authors declare no conflict of interest. The founding sponsors of this article had no role in the design of the study; in the collection, analyses, or interpretation of data; in the writing of the manuscript, and in the decision to publish the results.

\section{References}

1. Parmar, G.R.; Rao, N.N. Emerging Control Technologies for Volatile Organic Compounds. Crit. Rev. Environ. Sci. Technol. 2008, 39, 41-78. [CrossRef]

2. Baek, S.-W.; Kim, J.-R.; Ihm, S.-K. Design of dual functional adsorbent/catalyst system for the control of VOC's by using metal-loaded hydrophobic Y-zeolites. Catal. Today 2004, 93-95, 575-581. [CrossRef]

3. Fan, Z.; Lioy, P.; Weschler, C.; Fiedler, N.; Kipen, H.; Zhang, J. Ozone-Initiated Reactions with Mixtures of Volatile Organic Compounds under Simulated Indoor Conditions. Environ. Sci. Technol. 2003, 37, 1811-1821. [CrossRef]

4. Megías-Sayago, C.; Lara-Ibeas, I.; Wang, Q.; Le Calvé, S.; Louis, B. Volatile organic compounds (VOCs) removal capacity of ZSM-5 zeolite adsorbents for near real-time BTEX detection. J. Environ. Chem. Eng. 2020, 8, 103724. [CrossRef]

5. Kim, K.-H.; Kabir, E.; Kabir, S. A review on the human health impact of airborne particulate matter. Environ. Int. 2015, 74, 136-143. [CrossRef] [PubMed]

6. Zhang, X.; Gao, B.; Zheng, Y.; Hu, X.; Creamer, A.E.; Annable, M.D.; Li, Y. Biochar for volatile organic compound (VOC) removal: Sorption performance and governing mechanisms. Bioresour. Technol. 2017, 245, 606-614. [CrossRef]

7. Adnew, G.A.; Meusinger, C.; Bork, N.; Gallus, M.; Kyte, M.; Rodins, V.; Rosenørn, T.; Johnson, M.S. Gas-phase advanced oxidation as an integrated air pollution control technique. AIMS Environ. Sci. 2016, 3, 141-158. [CrossRef]

8. Ojala, S.; Pitkäaho, S.; Laitinen, T.; Koivikko, N.N.; Brahmi, R.; Gaálová, J.; Kucherov, A.; Matejova, L.; Päivärinta, S.; Hirschmann, C.; et al. Catalysis in VOC Abatement. Top. Catal. 2011, 54, 1224-1256. [CrossRef]

9. Tidahy, H.L.; Siffert, S.; Lamonier, J.F.; Cousin, R.; Zhilinskaya, E.A.; Aboukaïs, A.; Su, B.L.; Canet, X.; De Weireld, G.; Frère, M.; et al. Influence of the exchanged cation in Pd/BEA and Pd/FAU zeolites for catalytic oxidation of VOCs. Appl. Catal. B Environ. 2007, 70, 377-383. [CrossRef]

10. Joung, H.J.; Kim, J.H.; Oh, J.S.; You, D.W.; Park, H.O.; Jung, K.W. Catalytic oxidation of VOCs over CNT-supported platinum nanoparticles. Appl. Surf. Sci. 2014, 290. [CrossRef]

11. Antunes, A.P.; Ribeiro, M.F.; Silva, J.M.; Ribeiro, F.R.; Magnoux, P.; Guisnet, M. Catalytic oxidation of toluene over CuNaHY zeolites: Coke formation and removal. Appl. Catal. B Environ. 2001, 33, 149-164. [CrossRef]

12. Huang, H.; Xu, Y.; Feng, Q.; Leung, D.Y.C. Low temperature catalytic oxidation of volatile organic compounds: A review. Catal. Sci. Technol. 2015, 5, 2649-2669. [CrossRef]

13. Berenjian, A.; Khodiev, A. How ozone can affect volatile organic compounds. Aust. J. Basic Appl. Sci. 2009, 3, 385-388.

14. Rezaei, E.; Soltan, J.; Chen, N. Catalytic oxidation of toluene by ozone over alumina supported manganese oxides: Effect of catalyst loading. Appl. Catal. B Environ. 2013, 136-137, 239-247. [CrossRef]

15. Long, L.P.; Zhao, J.G.; Yang, L.X.; Fu, M.L.; Wu, J.L.; Huang, B.C.; Ye, D.Q. Room Temperature Catalytic Ozonation of Toluene over $\mathrm{MnO}_{2} / \mathrm{Al}_{2} \mathrm{O}_{3}$. Chin. J. Catal. 2011, 32, 904-916. [CrossRef]

16. Rezaei, E.; Soltan, J. Low temperature oxidation of toluene by ozone over MnOx/alumina and MnOx/MCM-41 catalysts. Chem. Eng. J. 2012, 198-199, 482-490. [CrossRef]

17. Nawrocki, J.; Kasprzyk-Hordern, B. The efficiency and mechanisms of catalytic ozonation. Appl. Catal. B Environ. 2010, 99, 27-42. [CrossRef]

18. Rezaei, F.; Moussavi, G.; Bakhtiari, A.R.; Yamini, Y. Toluene removal from waste air stream by the catalytic ozonation process with $\mathrm{MgO} / \mathrm{GAC}$ composite as catalyst. J. Hazard. Mater. 2016, 306, 348-358. [CrossRef]

19. Liu, Y.; Li, X.; Liu, J.; Shi, C.; Zhu, A. Ozone catalytic oxidation of benzene over AgMn/HZSM-5 catalysts at room temperature: Effects of Mn loading and water content. Cuihua Xuebao Chin. J. Catal. 2014, 35, 1465-1474. [CrossRef]

20. Huang, H.; Ye, X.; Huang, W.; Chen, J.; Xu, Y.; Wu, M.; Shao, Q.; Peng, Z.; Ou, G.; Shi, J.; et al. Ozone-catalytic oxidation of gaseous benzene over MnO2/ZSM-5 at ambient temperature: Catalytic deactivation and its suppression. Chem. Eng. J. 2015, 264, 24-31. [CrossRef]

21. Einaga, H.; Maeda, N.; Yamamoto, S.; Teraoka, Y. Catalytic properties of copper-manganese mixed oxides supported on $\mathrm{SiO}_{2}$ for benzene oxidation with ozone. Catal. Today 2015, 245, 22-27. [CrossRef]

22. Gopi, T.; Swetha, G.; Shekar, S.C.; Krishna, R.; Ramakrishna, C.; Saini, B.; Rao, P.V.L.V.L. Ozone catalytic oxidation of toluene over 13X zeolite supported metal oxides and the effect of moisture on the catalytic process. Arab. J. Chem. 2016, 12, 4502-4513. [CrossRef] 
23. Kim, H.-H.; Sugasawa, M.; Hirata, H.; Teramoto, Y.; Kosuge, K.; Negishi, N.; Ogata, A. Ozone-assisted catalysis of toluene with layered ZSM-5 and Ag/ZSM-5 zeolites. Plasma Chem. Plasma Process. 2013, 33, 1083-1098. [CrossRef]

24. Liu, B.; Ji, J.; Zhang, B.; Huang, W.; Gan, Y.; Leung, D.Y.C.; Huang, H. Catalytic ozonation of VOCs at low temperature: A comprehensive review. J. Hazard. Mater. 2021, 126847. [CrossRef]

25. Wang, H.C.; Liang, H.S.; Chang, M.B. Ozone-enhanced catalytic oxidation of monochlorobenzene over iron oxide catalysts. Chemosphere 2011, 82, 1090-1095. [CrossRef] [PubMed]

26. Yang, C.; Miao, G.; Pi, Y.; Xia, Q.; Wu, J.; Li, Z.; Xiao, J. Abatement of various types of VOCs by adsorption/catalytic oxidation: A review. Chem. Eng. J. 2019, 370, 1128-1153. [CrossRef]

27. Guo, Y.; Wen, M.; Li, G.; An, T. Recent advances in VOC elimination by catalytic oxidation technology onto various nanoparticles catalysts: A critical review. Appl. Catal. B Environ. 2021, 281, 119447. [CrossRef]

28. Brodu, N.; Zaitan, H.; Manero, M.-H.; Pic, J.-S. Removal of volatile organic compounds by heterogeneous ozonation on microporous synthetic alumina silicate. Water Sci. Technol. 2012, 66, 2020-2026. [CrossRef]

29. Soylu, G.S.P.; Özçelik, Z.; Boz, İ.I. Total oxidation of toluene over metal oxides supported on a natural clinoptilolite-type zeolite. Chem. Eng. J. 2010, 162, 380-387. [CrossRef]

30. Nikolov, P.; Genov, K.; Konova, P.; Milenova, K.; Batakliev, T.; Georgiev, V.; Kumar, N.; Sarker, D.K.; Pishev, D.; Rakovsky, S. Ozone decomposition on $\mathrm{Ag} / \mathrm{SiO} 2$ and $\mathrm{Ag} /$ clinoptilolite catalysts at ambient temperature. J. Hazard. Mater. 2010, 184, 16-19. [CrossRef]

31. Valdés, H.; Tardón, R.F.; Zaror, C.A. Role of surface hydroxyl groups of acid-treated natural zeolite on the heterogeneous catalytic ozonation of methylene blue contaminated waters. Chem. Eng. J. 2012, 211-212, 388-395. [CrossRef]

32. Alejandro-Martín, S.; Valdés, H.; Manero, M.-H.; Zaror, C. Catalytic Ozonation of Toluene Using Chilean Natural Zeolite: The Key Role of Brønsted and Lewis Acid Sites. Catalysts 2018, 8, 211. [CrossRef]

33. Valdés, H.; Ulloa, F.J.; Solar, V.A.; Cepeda, M.S.; Azzolina-Jury, F.; Thibault-Starzyk, F. New insight of the influence of acidic surface sites of zeolite on the ability to remove gaseous ozone using operando DRIFTS studies. Microporous Mesoporous Mater. 2020, 294, 109912. [CrossRef]

34. Wu, J.; Su, T.; Jiang, Y.; Xie, X.; Qin, Z.; Ji, H. In situ DRIFTS study of $\mathrm{O}_{3}$ adsorption on $\mathrm{CaO}, \gamma-\mathrm{Al}_{2} \mathrm{O}_{3}, \mathrm{CuO}, \alpha-\mathrm{Fe}_{2} \mathrm{O}_{3}$ and $\mathrm{ZnO}$ at room temperature for the catalytic ozonation of cinnamaldehyde. Appl. Surf. Sci. 2017, 412, 290-305. [CrossRef]

35. Roque Malherbe, R.; Wendelbo, R. Study of Fourier transform infrared-temperature-programmed desorption of benzene, toluene and ethylbenzene from H-ZSM-5 and H-Beta zeolites. Thermochim. Acta 2003, 400, 165-173. [CrossRef]

36. Einaga, H.; Futamura, S. Catalytic oxidation of benzene with ozone over alumina-supported manganese oxides. J. Catal. 2004, 227, 304-312. [CrossRef]

37. Einaga, H.; Ogata, A. Benzene oxidation with ozone over supported manganese oxide catalysts: Effect of catalyst support and reaction conditions. J. Hazard. Mater. 2009, 164, 1236-1241. [CrossRef] [PubMed]

38. Dhandapani, B.; Oyama, S.T. Gas phase ozone decomposition catalysts. Appl. Catal. B Environ. 1997, 11, 129-166. [CrossRef]

39. Li, W.; Oyama, S.T. Mechanism of Ozone Decomposition on a Manganese Oxide Catalyst. 2. Steady-State and Transient Kinetic Studies. J. Am. Chem. Soc. 1998, 120, 9047-9052. [CrossRef]

40. Einaga, H.; Futamura, S. Comparative study on the catalytic activities of alumina-supported metal oxides for oxidation of benzene and cyclohexane with ozone. React. Kinet. Catal. Lett. 2004, 81, 121-128. [CrossRef]

41. Oyama, S.T. Chemical and Catalytic Properties of Ozone. Catal. Rev. Sci. Eng. 2000, 42, 279-322. [CrossRef]

42. Kasprzyk-Hordern, B.; Ziólek, M.; Nawrocki, J. Catalytic ozonation and methods of enhancing molecular ozone reactions in water treatment. Appl. Catal. B Environ. 2003, 46, 639-669. [CrossRef]

43. Bulanin, K.M.; Lavalley, J.C.; Tsyganenko, A.A. IR spectra of adsorbed ozone. Colloids Surf. A Physicochem. Eng. Asp. 1995, 101, 153-158. [CrossRef]

44. Bulanin, K.M.; Lavalley, J.C.; Tsyganenko, A.A. Infrared Study of Ozone Adsorption on CaO. J. Phys. Chem. B 1997, 101, $2917-2922$. [CrossRef]

45. Hu, M.; Hui, K.S.; Hui, K.N. Role of graphene in $\mathrm{MnO}_{2}$ /graphene composite for catalytic ozonation of gaseous toluene. Chem. Eng. J. 2014, 254, 237-244. [CrossRef]

46. Jeon, J.Y.; Kim, H.Y.; Woo, S.I. Mechanistic study on the SCR of $\mathrm{NO}$ by $\mathrm{C}_{3} \mathrm{H}_{6}$ over Pt/V/MCM-41. Appl. Catal. B Environ. 2003, 44, 301-310. [CrossRef]

47. Chen, X.-M.; Yang, X.-F.; Zhu, A.-M.; Fan, H.-Y.; Wang, X.-K.; Xin, Q.; Zhou, X.-R.; Shi, C. In situ DRIFTS study on the partial oxidation of ethylene over Co-ZSM-5 catalyst. Catal. Commun. 2009, 10, 428-432. [CrossRef]

48. Alejandro, S.; Valdés, H.; Manéro, M.-H.; Zaror, C.A. Oxidative regeneration of toluene-saturated natural zeolite by gaseous ozone: The influence of zeolite chemical surface characteristics. J. Hazard. Mater. 2014, 274, 212-220. [CrossRef]

49. Rezaei, E.; Soltan, J.; Chen, N.; Lin, J. Effect of noble metals on activity of MnOx/ $\gamma$-alumina catalyst in catalytic ozonation of toluene. Chem. Eng. J. 2013, 214, 219-228. [CrossRef]

50. Kim, J.; Kwon, E.E.; Lee, J.E.; Jang, S.-H.; Jeon, J.-K.; Song, J.; Park, Y.-K. Effect of zeolite acidity and structure on ozone oxidation of toluene using Ru-Mn loaded zeolites at ambient temperature. J. Hazard. Mater. 2021, 403, 123934. [CrossRef]

51. Van Durme, J.; Dewulf, J.; Sysmans, W.; Leys, C.; Van Langenhove, H. Abatement and degradation pathways of toluene in indoor air by positive corona discharge. Chemosphere 2007, 68, 1821-1829. [CrossRef] [PubMed] 
52. Li, J.; Na, H.; Zeng, X.; Zhu, T.; Liu, Z. In situ DRIFTS investigation for the oxidation of toluene by ozone over Mn/HZSM-5, Ag/HZSM-5 and Mn-Ag/HZSM-5 catalysts. Appl. Surf. Sci. 2014, 311, 690-696. [CrossRef]

53. Huang, H.; Li, W. Destruction of toluene by ozone-enhanced photocatalysis: Performance and mechanism. Appl. Catal. B Environ. 2011, 102, 449-453. [CrossRef]

54. Huang, H.; Ye, D.; Leung, D.Y.C.; Feng, F.; Guan, X. Byproducts and pathways of toluene destruction via plasma-catalysis. J. Mol. Catal. A Chem. 2011, 336, 87-93. [CrossRef]

55. Brodu, N.; Manero, M.-H.; Andriantsiferana, C.; Pic, J.-S.; Valdés, H. Role of Lewis acid sites of ZSM-5 zeolite on gaseous ozone abatement. Chem. Eng. J. 2013, 231, 281-286. [CrossRef]

56. Brodu, N.; Manero, M.-H.; Andriantsiferana, C.; Pic, J.-S.; Valdés, H. Gaseous ozone decomposition over high silica zeolitic frameworks. Can. J. Chem. Eng. 2018, 96, 1911-1918. [CrossRef]

57. Brodu, N.; Sochard, S.; Andriantsiferana, C.; Pic, J.-S.; Manero, M.-H. Fixed-bed adsorption of toluene on high silica zeolites: Experiments and mathematical modelling using LDF approximation and a multisite model. Environ. Technol. 2015, 36, 1807-1818. [CrossRef]

58. Chao, C.Y.H.; Kwong, C.W.; Hui, K.S. Potential use of a combined ozone and zeolite system for gaseous toluene elimination. J. Hazard. Mater. 2007, 143, 118-127. [CrossRef]

59. Einaga, H.; Futamura, S. Catalytic oxidation of benzene with ozone over Mn ion-exchanged zeolites. Catal. Commun. 2007, 8, 557-560. [CrossRef]

60. Harris, D.C. Nonlinear least-squares curve fitting with Microsoft Excel Solver. J. Chem. Educ. 1998, 75, 119. [CrossRef]

61. Toby, S.; Van de Burgt, L.J.; Toby, F.S. Kinetics and chemiluminescence of ozone-aromatic reactions in the gas phase. J. Phys. Chem. 1985, 89, 1982-1986. [CrossRef]

62. Hu, M.; Yao, Z.; Hui, K.N.; Hui, K.S. Novel mechanistic view of catalytic ozonation of gaseous toluene by dual-site kinetic modelling. Chem. Eng. J. 2017, 308, 710-718. [CrossRef]

63. Rezaei, E.; Soltan, J. EXAFS and kinetic study of MnOx/ $\gamma$-alumina in gas phase catalytic oxidation of toluene by ozone. Appl. Catal. B Environ. 2014, 148-149, 70-79. [CrossRef]

64. Aghbolaghy, M.; Soltan, J.; Chen, N. Low Temperature Catalytic Oxidation of Binary Mixture of Toluene and Acetone in the Presence of Ozone. Catal. Lett. 2018, 148, 3431-3444. [CrossRef]

65. Scott, H.F. Elements of Chemical Reaction Engineering, 5th ed.; Prentice Hall: Boston, MA, USA, 2016; Volume 54, ISBN 0133887820.

66. Vannice, M.A. Kinetics of Catalytic Reactions; Springer: Boston, MA, USA, 2005; ISBN 978-0-387-24649-9.

67. Alejandro, S.; Valdés, H.; Zaror, C.A. Natural Zeolite Reactivity towards Ozone: The Role of Acid Surface Sites. J. Adv. Oxid. Technol. 2011, 14, 182-189. [CrossRef]

68. Alejandro, S.; Valdés, H.; Manero, M.-H.; Zaror, C.A. BTX abatement using Chilean natural zeolite: The role of Bronsted acid sites. Water Sci. Technol. 2012, 66, 1759-1769. [CrossRef]

69. Roque-Malherbe, R.; Ivanov, V. Codiffusion and counterdiffusion of para-xylene and ortho-xylene in a zeolite with $10 \mathrm{MR} / 12 \mathrm{MR}$ interconnected channels. An example of molecular traffic control. J. Mol. Catal. A Chem. 2009, 313, 7-13. [CrossRef]

70. Roque-Malherbe, R. Complementary approach to the volume filling theory of adsorption in zeolites. Microporous Mesoporous Mater. 2000, 41, 227-240. [CrossRef]

71. Valdés, H.; Alejandro, S.; Zaror, C.A. Natural zeolite reactivity towards ozone: The role of compensating cations. J. Hazard. Mater. 2012, 227-228, 34-40. [CrossRef]

72. Valdés, H.; Farfán, V.J.; Manoli, J.A.; Zaror, C.A. Catalytic ozone aqueous decomposition promoted by natural zeolite and volcanic sand. J. Hazard. Mater. 2009, 165, 915-922. [CrossRef] [PubMed]

73. Guisnet, M.; Ayrault, P.; Coutanceau, C.; Fernanda Alvarez, M.; Datka, J. Acid properties of dealuminated beta zeolites studied by IR spectroscopy. J. Chem. Soc. Faraday Trans. 1997, 93, 1661-1665. [CrossRef]

74. Abreu, N.J.; Valdés, H.; Zaror, C.A.; Azzolina-Jury, F.; Meléndrez, M.F. Ethylene adsorption onto natural and transition metal modified Chilean zeolite: An operando DRIFTS approach. Microporous Mesoporous Mater. 2019, 274, 138-148. [CrossRef] 